\title{
Schizorhynchia Meixner, 1928 (Platyhelminthes, Rhabdocoela) of the Iberian Peninsula, with a description of four new species from Portugal
}

\author{
Stefan GOBERT ${ }^{1}$, Marlies MONNENS ${ }^{2, *}$, Lise EERDEKENS ${ }^{3}$, \\ Ernest SCHOCKAERT ${ }^{4}$, Patrick REYGEL ${ }^{5} \&$ Tom ARTOIS ${ }^{6}$
}

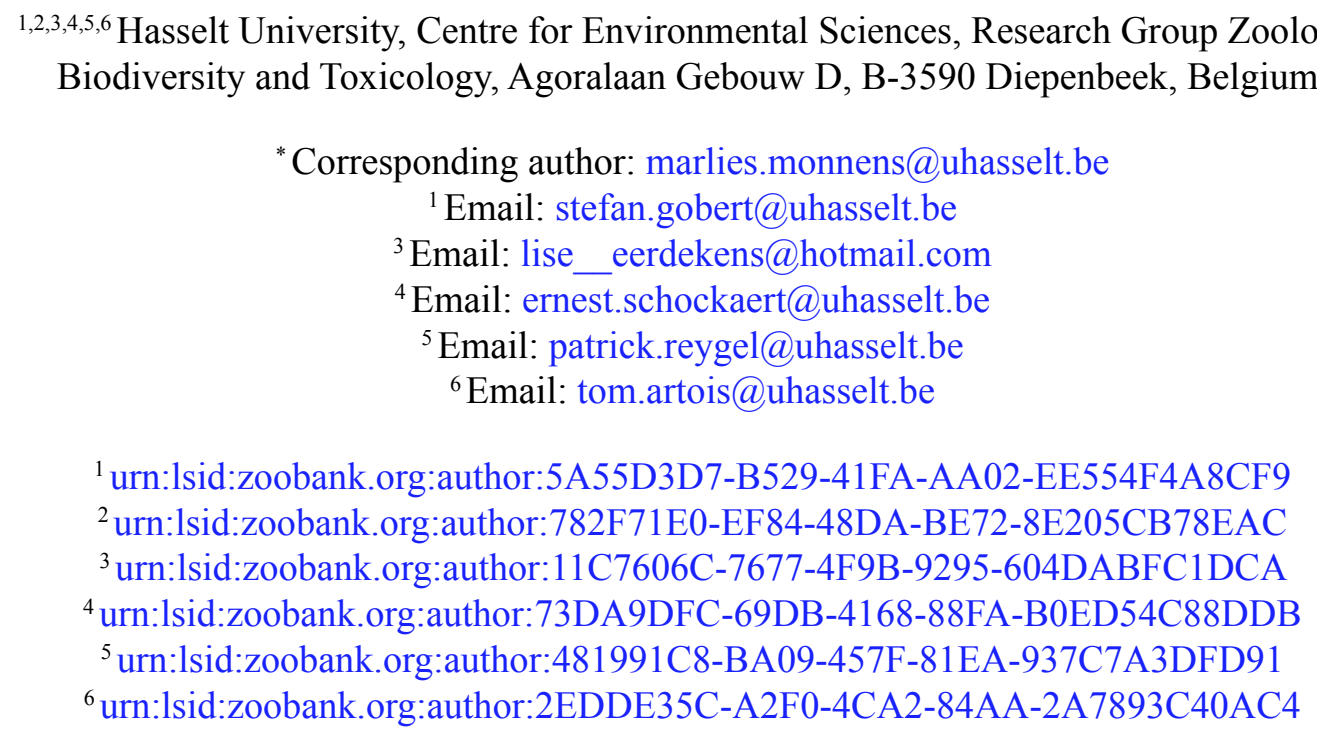

\begin{abstract}
During several sampling campaigns in the regions of Galicia and Andalusia in Spain and the Algarve region in Portugal, specimens of twelve species of schizorhynch rhabdocoels were collected. Four of these are new to science: three species of Proschizorhynchus (P. algarvensis sp. nov., P. arnautsae sp. nov. and P. troglodytus sp. nov.) and one species of Schizochilus (S. coninxae sp. nov.). The new species of Proschizorhynchus can be distinguished from their congeners by the curvature and length of their stylet, as well as the cirrus sheath and the organisation of the genital system. Schizochilus coninxae sp. nov. has a distinct two-part stylet that is unique within the genus. In addition to these new species, new data are reported for the diascorhynchid Diascorhynchus caligatus and the schizorhynchids Carcharodorhynchus multidentatus, C. tenuis, C. flavidus, Proschizorhynchus pectinatus and $P$. reniformis. Finally, new records for $C$. flavidus from the Hawaiian archipelago are presented.
\end{abstract}

Keywords. Kalyptorhynchia, microturbellarians, meiobenthos, systematics, taxonomy.

Gobert S., Monnens M., Eerdekens L., Schockaert E., Reygel P. \& Artois T. 2020. Schizorhynchia Meixner, 1928 (Platyhelminthes, Rhabdocoela) of the Iberian Peninsula, with a description of four new species from Portugal. European Journal of Taxonomy 595: 1-17. https://doi.org/10.5852/ejt.2020.595 


\section{Introduction}

The species-rich platyhelminth taxon Rhabdocoela Ehrenberg, 1831 consists of two sister clades: Kalyptorhynchia Graff, 1905, easily recognised by the presence of a proboscis at the anterior body end, and Dalytyphloplanida Willems, Wallberg, Jondelius, Littlewood, Schockaert \& Artois, 2006, which lack such an organ (Willems et al. 2006). Within Kalyptorhynchia, two major groups are distinguished: Eukalyptorhynchia Meixner, 1928, a paraphyletic assemblage of kalyptorhynchs with an undivided, conorhynch proboscis, and Schizorhynchia Meixner, 1928, a monophyletic group characterised by a split proboscis (Tessens et al. 2014).

So far, the study of microturbellarians in the Iberian Peninsula has focused primarily on non-marine environments (e.g., Gieysztor 1931; Farías et al. 1995; Gamo \& Noreña-Janssen 1998; Noreña et al. 1999). The brackish-water habitats of Galicia, Asturias, Cantabria and País Vasco (Noreña et al. 2007), the Doñana National Park in Andalusia (Van Steenkiste et al. 2011) and the Algarve (Schockaert 2014; Schockaert et al. 2017, 2019) have been investigated to some extent. In total, approximately 100 species of Rhabdocoela have been reported from freshwater habitats in the Iberian Peninsula, the majority of which belong to Dalytyphloplanida (Tyler et al. 2006-2019a; Van Steenkiste et al. 2011). Only 14 species of Kalyptorhynchia are known from the Iberian Peninsula (Noreña et al. 2007; Schockaert et al. 2017). Five of these belong to Schizorhynchia: Baltoplana magna Karling, 1949, Cheliplana cf. setosa Evdonin, 1971, Proschizorhynchus martinezi Gobert, Reygel \& Artois, 2017 and two records of unidentified species of Karkinorhynchus Meixner, 1928 (Noreña et al. 2007; Gobert et al. 2017).

As part of an investigation into the systematics of Schizorhynchia as a whole, sampling was undertaken in various locations across the Iberian Peninsula, including Galicia (August 2008) and Andalusia (March-April 2008) in Spain, as well as the Algarve region in Portugal (September 2011, September 2012, May 2013, September 2014). In this paper, we provide an overview of the schizorhynch taxa found during these sampling campaigns. All twelve of the species found are new to the region and four are new to science. In addition, we report a number of new geographic records for some of these species outside of the Iberian Peninsula.

\section{Material and methods}

Specimens were collected from coastal regions throughout the Iberian Peninsula. Sampling was performed at different time points in the summer and springtime of 2008, 2011, 2012, 2013 and 2014. Sand samples were either retrieved from beaches or the subtidal zone. In the latter case, sediment was obtained manually or with a slurp gun by diving. Conspecific specimens collected during previous sampling campaigns by members of the Zoology group at Hasselt University are also included in this work. This includes specimens from several locations in Hawaii, USA. Exact localities of these and the newly obtained material are listed for each species in the results section.

Meiofaunal interstitial kalyptorhynchs were extracted from the sediment using the $\mathrm{MgCl}_{2}$-decantation method (Schockaert 1996). Collected specimens were studied and drawn alive. Of each species, at least one specimen was whole-mounted in lactophenol. Whole-mounts were later studied in detail using Nomarski interference contrast microscopy (Leica DM 2500 and Reichert-Jung Polyvar). Measurements were taken axially unless indicated otherwise. The position of organs in the body is expressed as a percentage of the body length. All material, including holotypes, is deposited in the collection of Hasselt University (HU numbers).
Abbreviations
$\mathrm{b}=$ bursa
$\mathrm{cb}=$ copulatory bulb 


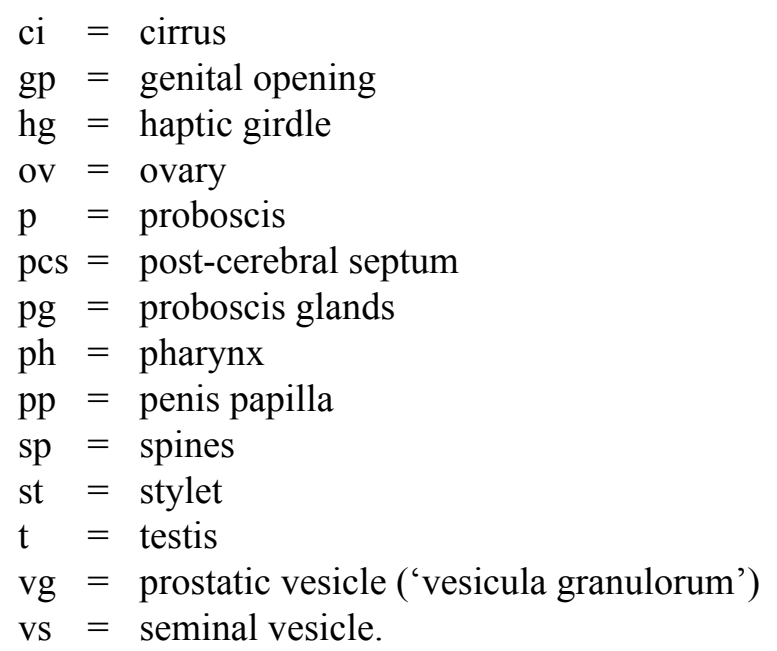

\section{Results}

Class Rhabditophora Ehlers, 1985

Subclass Trepaxonemata Ehlers, 1984

Order Rhabdocoela Ehrenberg, 1831

Suborder Kalyptorhynchia Graff, 1905

Infraorder Schizorhynchia Meixner, 1928

Family Schizorhynchidae Graff, 1905

Genus Schizochilus Boaden, 1963

Schizochilus coninxae sp. nov. urn:1sid:zoobank.org:act:001130A5-1784-4395-8619-0D5AD614007D

Fig. $1 \mathrm{~A}-\mathrm{C}$

\section{Etymology}

This species is named in honour of Hasselt University researcher and close friend to the first author, Laura Coninx.

\section{Material examined}

\section{Holotype}

PORTUGAL - 1 whole-mount; Algarve region, lagoon near the CCMAR Ramalhete research station; 19 Sep. 2012; E. Schockaert leg.; high eulittoral zone, medium-fine sand among Spartina von Schreber, little detritus or silt, reduced layer more than $5 \mathrm{~cm}$ deep; HU 614.

\section{Other material}

PORTUGAL -3 whole-mounts (two of these of insufficient quality for taxonomic work); same collection data as for holotype; HU X.1.32 2 whole-mounts (photographs of live specimens available); Olhos de Água; $37^{\circ} 05^{\prime} 20^{\prime \prime} \mathrm{N}, 08^{\circ} 11^{\prime} 17^{\prime \prime} \mathrm{W}$; 15 May 2013; B. Tessens leg.; dry sand and algae mixture collected from eastern side of a rocky outcrop; HU X.1.33-X.1.34.

\section{Description}

Specimens approximately $2 \mathrm{~mm}$ long, measured on whole-mounts. Eyes are absent. The anteriorlypositioned proboscis (p, Fig. 1A) is relatively small ( $(1 / 10-1 / 8$ of the total body length). A pharynx rosulatus (ph, Fig. 1A) is present in the caudal body half. A single, seemingly continuous haptic girdle is present at the caudal body end. 
The common genital opening is situated in the posterior, at about $80 \%$. A single row of four globular testes (t, Fig. 1A) is present anterior to the pharynx. A pair of seminal vesicles (vs, Fig. 1A) enter the proximal end of an elongate copulatory bulb separately. A large prostatic vesicle (vg, Fig. 1A) occupies the proximal half of the copulatory bulb. The walls of the copulatory bulb are muscular, with several
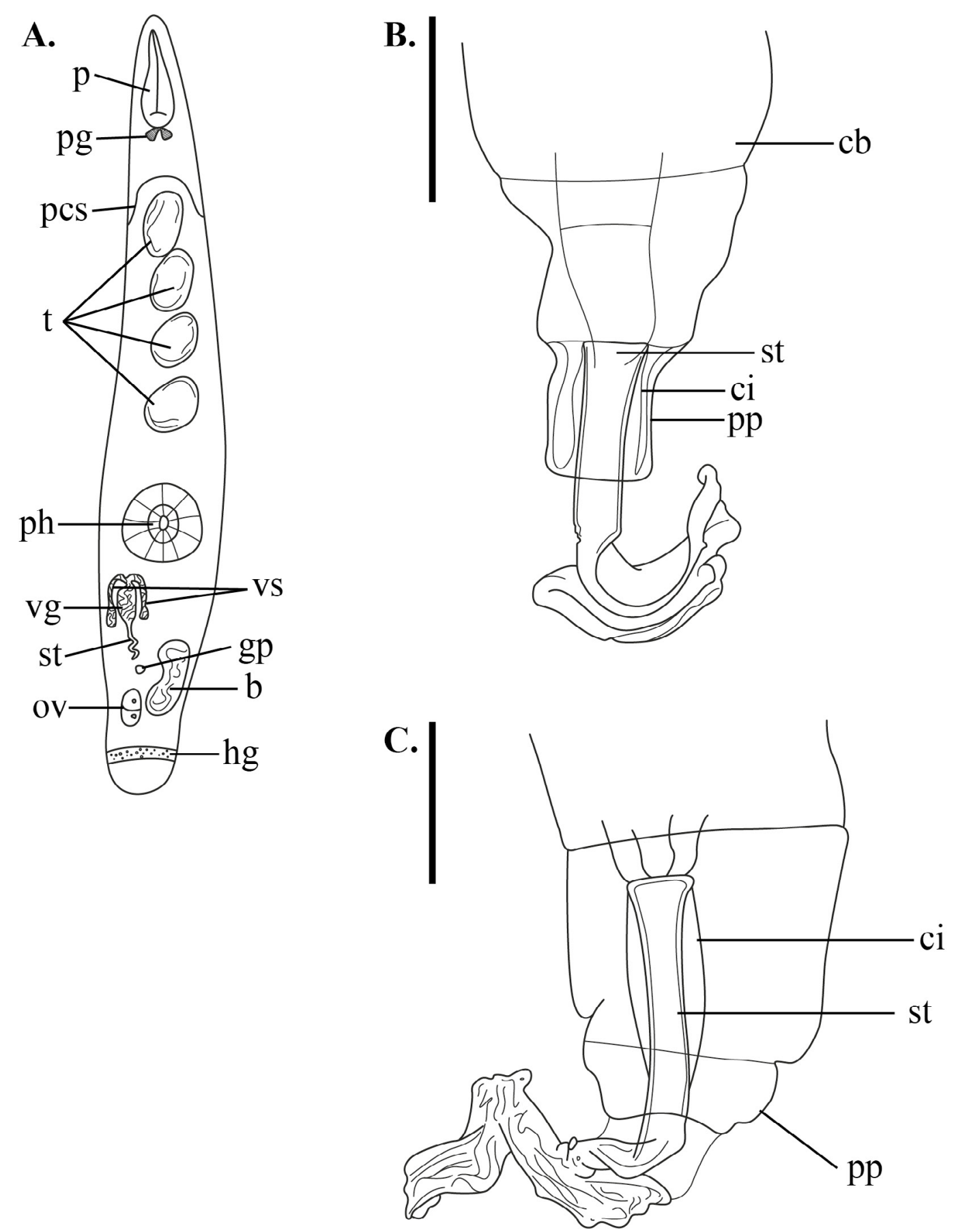

Fig. 1. Schizochilus coninxae sp. nov. A. Habitus of live specimen collected at the type locality. B-C. Distal end of the copulatory bulb, with stylet and penis papilla. B. Holotype (HU 614). C. A specimen from the reference collection of Hasselt University (HU X.1.32). Scale bars: $20 \mu \mathrm{m}$. 
marked constrictions present along the length of the bulb. The distal part contains the stylet (st, Fig 1AC). The stylet consists of a straight, tubular proximal part, 17-22 $\mu \mathrm{m}$ long $(\overline{\mathrm{x}}=20 \mu \mathrm{m}, \mathrm{n}=4)$ and with a diameter of $5 \mu \mathrm{m}$, and an irregular, folded 'plate'- or 'sheet'-like distal part. The sheet-like distal part is a rather flexible extension that can be positioned anywhere from perpendicular to the tubular part of the stylet, to lying in its extension. In some live specimens, this part was twisted into a corkscrewlike shape. The entire stylet measures $58-63 \mu \mathrm{m}(\overline{\mathrm{x}}=60 \mu \mathrm{m}, \mathrm{n}=4)$ and lies within a thin-walled, unarmed cirrus. The distal part of the copulatory bulb forms a sclerotised penis papilla, which measures approximately $20 \mu \mathrm{m}$.

\section{Remarks}

The unarmed, elongate, split proboscis unambiguously places the new species in the family Schizorhynchidae. The combination of testes organisation in a single row, a pharynx occurring in the second body half and the sclerotised part of the copulatory organ consisting of (at least) a cirrus indicates that the specimens we retrieved belong to the genus Schizochilus Boaden, 1963.

A tubular stylet is present within the cirrus, similar to the organisation of the copulatory organ in S. bruneti Noldt \& Hoxhold, 1984, S. caecus 1'Hardy, 1963, S. choriurus Boaden, 1963, S. hoxholdi Karling, 1989, S. tubulatus Brunet, 1970, S. parvulus Brunet, 1970, S. santacruzensis Noldt \& Hoxhold, 1984 and S. lanzarotensis Gobert, Reygel \& Artois, 2017. Whereas in most of these species the cirrus is at least partly covered with spines, this is not the case in our specimens, nor in S. tubulatus or S. bruneti. Our specimens differ from the latter two species in the sclerotisation of the cirrus: in $S$. tubulatus and S. bruneti, the cirrus is thick and characterised by longitudinal grooves, while it is only lightly sclerotised in our specimens. Moreover, the distal sheet-like part we observed is unique for Schizochilus and justifies the establishment of a new species: $S$. coninxae sp. nov.

\section{Genus Proschizorhynchus Meixner, 1928}

In the past, different terminologies have been used to describe the copulatory structures in Proschizorhynchus (e.g., l'Hardy 1965; Noldt 1985). Here, we apply the terminology put forward by Noldt (1985), as this work comprises the most extensive overview of the genus to date.

Proschizorhynchus algarvensis sp. nov.

urn:1sid:zoobank.org:act:B9703F24-3367-4329-BFB0-8A36051890B0

Fig. 2A

\section{Etymology}

The species epithet, 'algarvensis', refers to the Algarve region of southern Portugal, where the specimen was collected.

\section{Material examined}

Holotype

PORTUGAL 1 whole-mount (photographs of live specimen available); Algarve region, Sagres, east of Mareta beach; $37^{\circ} 00^{\prime} 10^{\prime \prime} \mathrm{N}, 08^{\circ} 56^{\prime} 06^{\prime \prime} \mathrm{W} ; 20$ May 2013; B. Tessens leg.; coarse sand with shell gravel; HU 615.

\section{Description}

The living specimen is colourless. A pair of reniform eyes is present. A pair of small, round testes is situated in the anterior half of the body. The atrial genital organs are situated in the posterior quarter of the body, surrounding the common genital pore. A pair of seminal vesicles enters the proximal end of 
the elongate copulatory bulb, along with the gland necks of a number of prostatic glands. The distal part of the copulatory bulb contains the sclerotised parts of the copulatory apparatus (Fig. 2A). These consist of a stylet (st, Fig. 2A) enclosed by a sclerotised and grooved cirrus sheath (ci, Fig. 2A) and surrounded by a penis papilla (pp, Fig. 2A). The stylet measures $207 \mu \mathrm{m}$ and is curved back upon itself. The distal edge of the penis papilla is armed with rod-like spines (sp, Fig. 2A). The cirrus sheath surrounding the stylet measures $80 \mu \mathrm{m}$ and has a distal opening of $73 \mu \mathrm{m}$. A small, sclerotised, tubular spermatic duct connects the bursa to the single ovary.

\section{Remarks}

See taxonomic discussion following P. reniformis Brunet, 1970.

Proschizorhynchus arnautsae sp. nov. urn:1sid:zoobank.org:act:E581DF16-97C5-4F81-9702-BB79821AB620

Fig. 2B-C

\section{Etymology}

This species is named in honour of fellow Hasselt University researcher and dear friend to the first author, Natascha Arnauts.

\section{Material examined}

\section{Holotype}

PORTUGAL - 1 whole-mount (photographs of live specimen available); Olhão, Garganta Canal;

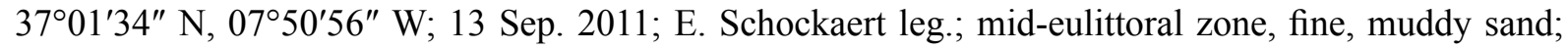
HU 616.

\section{Other material}

PORTUGAL 1 whole-mount (photographs of live specimen available); Algarve region, Faro, Parque

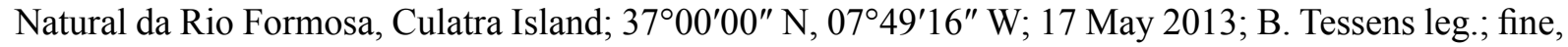
silty sand, with many bivalve shells and seagrass, from creek in a bay on the eastern shore of the island; HU X.1.35. 1 whole-mount (photographs of live specimen available); Algarve region, Olhos de Água; $37^{\circ} 05^{\prime} 20^{\prime \prime} \mathrm{N}, 08^{\circ} 11^{\prime} 16^{\prime \prime} \mathrm{W}$; 15 May 2013; B. Tessens leg.; coarse sand between rocks on the eastern side of a rocky outcrop; HU X.1.36 1 whole-mount (photographs of live specimen available); Algarve region, Olhos de Água; $37^{\circ} 05^{\prime} 20^{\prime \prime} \mathrm{N}, 08^{\circ} 11^{\prime} 16^{\prime \prime} \mathrm{W}$; 15 May 2013; B. Tessens leg.; fine clean sand from intertidal at open beach, about $0.5 \mathrm{~m}$ deep, west of rocky outcrop; HU X.1.37.

\section{Description}

Live specimens measure approximately $1.6 \mathrm{~mm}$ in length and are colourless. Eyes are absent. An elongate split proboscis, approximately $1 / 10$ of the total body length (when relaxed), is situated at the anterior end of the body. Connecting proximally to the muscular proboscis is a pair of small gland sacs. A rosulate pharynx is present in the anterior half of the body.

Two small, globular testes are positioned anterior to the pharynx. A pair of seminal vesicles enters an ovoid copulatory bulb, the proximal part of which is occupied by a prostatic bulb. Distally, the copulatory bulb contains the sclerotised copulatory parts (Fig. 2B-C), which consist of a very short, slender stylet, set in a cirrus sheath ornamented with parallel longitudinal grooves. The stylet is between 26 and $36 \mu \mathrm{m}$ long $(\overline{\mathrm{x}}=31 \mu \mathrm{m}, \mathrm{n}=4)$. In most specimens, the stylet is completely enveloped by the cirrus sheath, meaning the tip does not protrude beyond the distal rim of the copulatory organ. However, in some instances it can protrude a little (as in Fig. 2C), probably depending on the organ's contraction or flattening of the specimen. The distal rim of the cirrus sheath does not bear spines. 

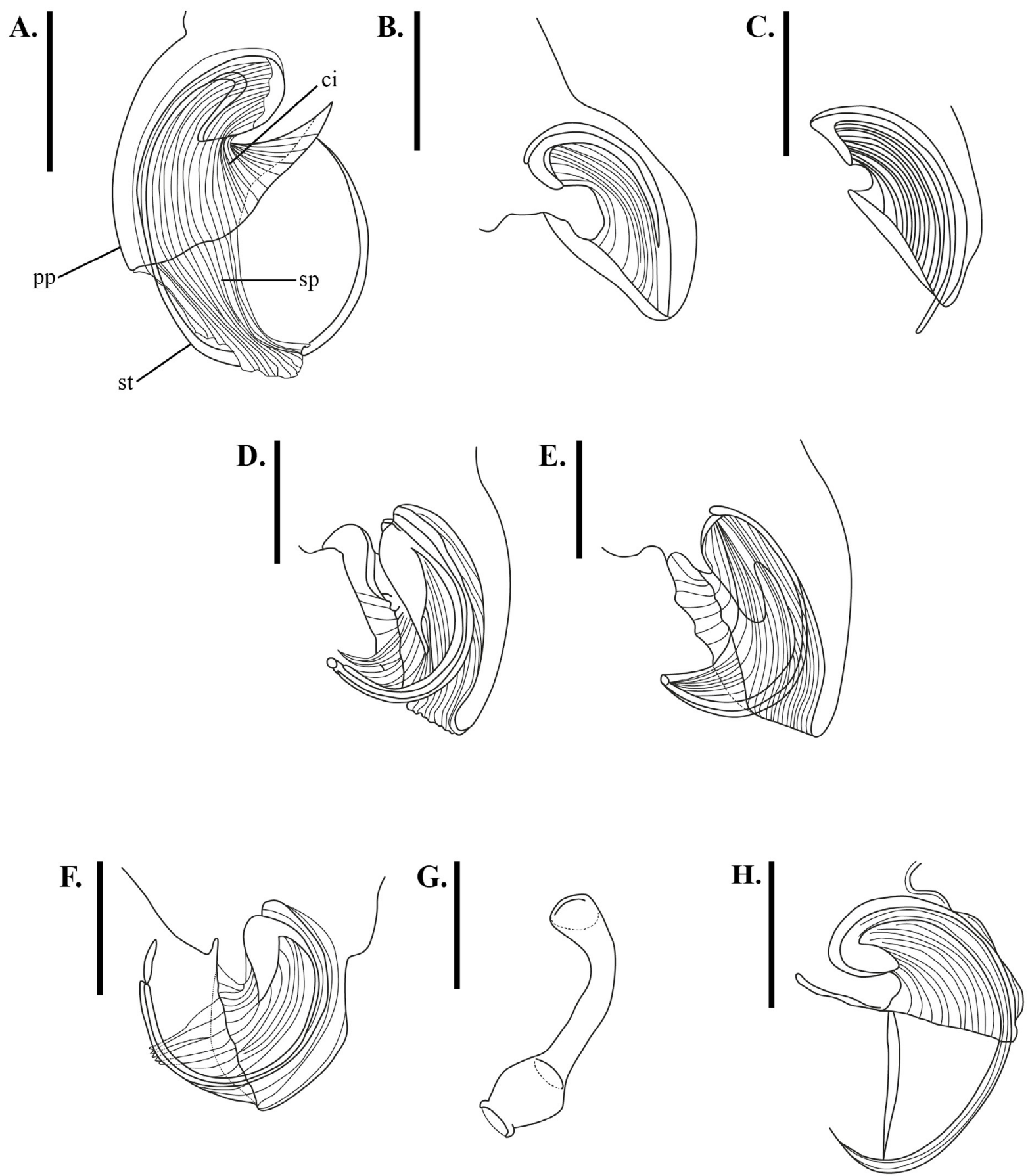

Fig. 2. Copulatory organ of species of Proschizorhynchus Meixner, 1928. A. Proschizorhynchus algarvensis sp. nov., holotype (HU 615). B-C. P. arnautsae sp. nov. B. Holotype (HU 616). C. A specimen from the reference collection of Hasselt University (HU X.1.35). D-E. P. troglodytus sp. nov. D. Holotype (HU 617). E. A specimen from the reference collection of Hasselt University (HU X.1.40). F-G. P. pectinatus 1'Hardy, 1965 (HU X.1.43). F. Copulatory organ. G. Sclerotised spermatic duct. H. P. reniformis Brunet, 1970 (HU X.1.45). Scale bars: A, F $=50 \mu \mathrm{m}$; B-E, G-H $=20 \mu \mathrm{m}$. 
The female genital system could not be studied in detail. A uterus and bursa were observed to lie caudally with respect to the male copulatory apparatus. A single ovary was observed even more caudally. Paired vitellaria run laterally along either side of the body.

\section{Remarks}

See taxonomic discussion following P. reniformis.

Proschizorhynchus troglodytus sp. nov. urn:Isid:zoobank.org:act:C0548D31-D347-4B4D-8990-9D72F7FD8CED

Fig. 2D-E

\section{Etymology}

The species epithet 'troglodytus', meaning 'cave-dweller', refers to the type locality, which is situated in a submerged cave.

\section{Material examined}

\section{Holotype}

PORTUGAL - 1 whole-mount (photographs of live specimen available); Algarve region, Carvoeiro, beach at Vale de Covo; 3705'34" N, 08 $27^{\prime} 33^{\prime \prime}$ W; 27 May 2013; B. Tessens leg.; fine, clean sand in rockpool near cave mouth at $1 \mathrm{~m}$ depth; HU 617.

\section{Other material}

PORTUGAL 1 whole-mount (photographs of live specimen available); Algarve region, Carvoeiro,

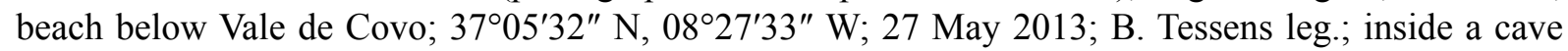
at about $0.5 \mathrm{~m}$ depth, fine to medium, clean sand, with fine shell debris; HU X.1.39 1 whole-mount (photographs of live specimen available); Algarve region, Carvoeiro, beach below Vale de Covo; $37^{\circ} 05^{\prime} 33^{\prime \prime} \mathrm{N}, 08^{\circ} 27^{\prime} 35^{\prime \prime} \mathrm{W}$; 27 May 2013; B. Tessens leg.; fine to medium, clean sand, with fine shell debris between rocks at beach in cave mouth, at low-water line; HU X.1.40.

\section{Description}

Specimens have a pair of pigmented eyes. The elongate, split proboscis is unarmed and lies at the anterior body end.

The copulatory apparatus consists of an elongate bulb, with a pair of small seminal vesicles entering it proximally. The distal end of the copulatory bulb holds the sclerotised copulatory apparatus. This consists of a long stylet with a plate-like, widened base, set in a grooved cirrus sheath and surrounded by a sclerotised penis papilla (Fig. 2D-E). The stylet is curved and measures $70-76 \mu \mathrm{m}(\overline{\mathrm{x}}=74, \mathrm{n}=3$ ) overall. Approximately the distal half of the stylet protrudes beyond the rim of the penis papilla when the copulatory organ is in its relaxed state. The distal rim of the cirrus sheath is lined with $25-\mu \mathrm{m}$-long, curved spines.

Vitellaria are paired and occur laterally. A single ovary is situated near the caudal end of the specimen. The collected material did not allow for a more detailed study of the female system.

\section{Remarks}

See taxonomic discussion following P. reniformis. 
Proschizorhynchus pectinatus l'Hardy, 1965

Fig. 2F-G

\section{Material examined}

PORTUGAL • 1 whole-mount; Algarve region, Faro, Ria Formosa; 3659'53" N, 0755'41" W; 19 Sep. 2012; E. Schockaert leg.; low eulittoral zone, loose sand with some organic detritus and very little silt; HU X.1.42.

SPAIN • 2 whole-mounts; Doñana National Park; 6 Apr. 2008; B. Tessens and N. Van Steenkiste leg.; sand with Arenicola marina (Linnaeus, 1758) Lamarck, 1801 collected from beach near the river mouth; HU X.1.43-X.1.44.

\section{Previously known distribution}

English Channel coast, France (l'Hardy 1965); near Marseille, France (Brunet 1970); Rhine-MeuseScheldt Delta, the Netherlands (Schockaert et al. 1989).

\section{Remarks}

Specimens eyeless, measuring 2.5-2.7 $\mathrm{mm}$ in length (measured on two whole-mounts). The stylet (Fig. 2F) is thin and strongly curved, with a widened proximal base. Distally, the stylet shows a small, spindle-like piece that is separated from the rest of the stylet by a narrow constriction. The entire stylet has a length of around $93-102 \mu \mathrm{m}(\overline{\mathrm{x}}=100 \mu \mathrm{m}, \mathrm{n}=3)$. The stylet is surrounded by a $49 \mu \mathrm{m}$ long curved cirrus sheath (cirrus in l'Hardy 1965) with parallel grooves. The distal edge of the sheath is armed with spines, measuring 24-30 $\mu \mathrm{m}$. These measurements are more or less in accordance with those provided by l'Hardy (1965). A tubular, sclerotised spermatic duct with a wide (bulbous) region at the bursa-facing end is present (Fig. 2G).

\section{Proschizorhynchus reniformis Brunet, 1970}

Fig. $2 \mathrm{H}$

\section{Material examined}

PORTUGAL 1 whole-mount (photographs of live specimen available); Algarve region, Sagres, East of Mareta Beach; $37^{\circ} 00^{\prime} 10^{\prime \prime} \mathrm{N}, 08^{\circ} 56^{\prime} 06^{\prime \prime} \mathrm{W} ; 20$ May 2013; B. Tessens leg.; coarse sand and shell gravel at $12 \mathrm{~m}$ depth; HU X.1.45.

\section{Previously known distribution}

Baie de Cassis, Provence-Alpes-Côte d'Azur, France (Brunet 1970).

\section{Remarks}

The slender, curved stylet measures $65 \mu \mathrm{m}$ in length and lies in a 30- $\mu \mathrm{m}$-long, grooved cirrus sheath (Fig. 2H). A sclerotised, plate-like structure, approximately $25 \mu \mathrm{m}$ in length, extends from the stylet's proximal base, perpendicular to the rim of the cirrus sheath, towards the distal end of the stylet. The stylet is slightly longer than the size range described by Brunet (1970), who mentions stylet lengths of 40-45 $\mu \mathrm{m}$. Otherwise, our specimen conforms well to the description of $P$. reniformis.

\section{Taxonomic discussion: Proschizorhynchus}

Proschizorhynchus is one of the most species-rich genera within Schizorhynchidae (Tyler et al. 20062019b). The genus is relatively uniform in its general morphology and is characterised by a copulatory organ consisting of a grooved cirrus sheath, a stylet and a hardened penial papilla (see Noldt 1985). 
The various species are distinguished from each other based largely on the structure of the copulatory organ.

The highly characteristic copulatory apparatus, with a sheath showing longitudinal striation, places our three newly-described species in the genus Proschizorhynchus. Within Schizorhynchia, only Typhlorhynchus Laidlaw, 1902 shares this feature of the male copulatory system. However, this genus is characterised by the lack of a proboscis, placing our specimens unambiguously within Proschizorhynchus.

The lack of spines or rods on the distal rim of the cirrus sheath in P. arnautsae sp. nov. is a feature shared with P. gullmarensis Karling, 1950, P. reniformis Brunet, 1970 and P. lunatus Brunet, 1970. In P. gullmarensis and P. reniformis, however, the stylet is much longer, protruding far beyond the rim of the cirrus sheath and, in P. reniformis, curved back upon itself. Furthermore, in both species, a bundle of spines is attached to the distal cirrus ridges (see Noldt \& Hoxhold 1984), a feature not seen in $P$. arnautsae sp. nov. Finally, both species have a larger plate-like extension at the base of the stylet that is not present either in P. arnautsae sp. nov.

Proschizorhynchus lunatus has a stylet comparable in length to that of $P$. arnautsae sp. nov. (30-35 $\mu \mathrm{m}$ and 26-36 $\mu \mathrm{m}$ long, respectively) and is generally similar in the proportions of the copulatory organ. However, in P. lunatus, the cirrus sheath forms the base of a curved, hardened distal penis, with a narrow distal opening (Brunet 1970; Noldt 1985). Such a structure is unique within the genus and was not observed in any of the specimens of $P$. arnautsae sp. nov. either.

Proschizorhynchus troglodytus sp. nov. resembles $P$. pectinatus l'Hardy, 1965 and $P$. arenarius de Beauchamp, 1927 in its strongly curved and very long (with respect to the cirrus sheath) stylet. Moreover, these three species all possess a plate-like extension at the base of the stylet, but this is shared with some other species within the genus (e.g., P. gullmarensis, see above). According to l'Hardy (1965), $P$. pectinatus and $P$. arenarius are very difficult to distinguish. This is, at least in part, due to the inadequate description of $P$. arenarius (see Noldt 1985). For example, it is unclear whether the continuation of the longitudinal ridges on the sheath of $P$. arenarius drawn and described by de Beauchamp (1927) represent spines of the type present in P. pectinatus and most other representatives of the genus, or are the result of partial eversion of the cirrus (Noldt 1985). Both P. troglodytus sp. nov. and P. pectinatus have a sclerotised piece at the distal end of the stylet that is somewhat separated from the rest by a slight constriction. However, in P. pectinatus this piece is leaf-shaped, while in P. troglodytus sp. nov. it is cylindrical and robust. In fact, the entire stylet of $P$. troglodytus sp. nov. has a thicker and more robust appearance than that of P. pectinatus. Furthermore, the stylet in P. troglodytus sp. nov. barely protrudes beyond the distal end of the spines on the cirrus sheath, while in P. pectinatus (and P. arenarius), the stylet is much longer relative to the cirrus sheath and spines.

The copulatory apparatus of $P$. algarvensis sp. nov. also bears a great resemblance to that of $P$. pectinatus in the shape of the stylet and the presence of long spines on the distal rim of the penis papilla. However, the stylet of $P$. algarvensis sp. nov. is longer and much more strongly curved than that of P. pectinatus (207 $\mu \mathrm{m}$ in P. algarvensis sp. nov., approx. $100 \mu \mathrm{m}$ in P. pectinatus). Moreover, it appears to protrude less far beyond the spines of the cirrus sheath in P. pectinatus than it does in P. algarvensis sp. nov. In $P$. pectinatus the stylet also has a distal constriction, which is lacking in $P$. algarvensis sp. nov. Furthermore, $P$. algarvensis sp. nov. has a pair of pigmented eyes, while P. pectinatus and $P$. arenarius are eyeless. 
GOBERT S. et al., Schizorhynchia of the Iberian Peninsula

Genus Carcharodorhynchus Meixner, 1938

Carcharodorhynchus tenuis Brunet, 1979

Fig. 3A-D

\section{Material examined}

PORTUGAL - 1 whole-mount (photographs of live specimen available); Algarve region, Sagres, eastward of Mareta beach; $37^{\circ} 00^{\prime} 10^{\prime \prime}$ N, 08 $56^{\prime} 06^{\prime \prime}$ W; 20 May 2013; B. Tessens leg.; coarse sand and shell gravel, depth 12 m; HU X.1.46.

\section{Previously known distribution}

Bay of Marseille, France (Brunet 1979).

\section{Remarks}

The specimen is eyeless. Live specimens are colourless and transparent. A single, continuous adhesive girdle is present at the caudal body end. A rosulate pharynx is present at about $65 \%$. The proboscis is highly asymmetrical: the ventral tongue measures approximately $44 \mu \mathrm{m}$, while the larger dorsal tongue measures $61 \mu \mathrm{m}$ in length. The proboscis armature consists of rows of small, triangular teeth. On the ventral proboscis tongue, four to six teeth are set in a single row on either side of the tongue, with the teeth increasing in size distally. These teeth have a basal diameter of up to $4 \mu \mathrm{m}$ and measure up to $3 \mu \mathrm{m}$ in length. On the dorsal proboscis tongue, the teeth are arranged in multiple rows. In the distal part of the proboscis, the teeth are largest, with a diameter of 1-2 $\mu \mathrm{m}$ and a length of approximately $2 \mu \mathrm{m}$. These are more or less set in a single row. In the middle section of the proboscis tongue, the proboscis teeth are small and form a field of 3-4 rows. At the base of the dorsal tongue, the teeth are once again arranged in a single row. In the area connecting the tongues, the teeth form another wider field of about three rows.

Two very long seminal vesicles enter the proximal end of the copulatory bulb. The proximal ends of the seminal vesicles lie on either side of the pharynx. The male copulatory system holds a sclerotised, conical cirrus with a length of $15 \mu \mathrm{m}$, armed with very fine spines. In our specimen, the proximal spines have a diameter of 3-4 $\mu \mathrm{m}$ in the proximal region and $11-12 \mu \mathrm{m}$ in the distal region of the cirrus. The male copulatory bulb connects to the male atrium, which is surrounded by circular to slightly diagonal muscles and leads into the common genital atrium. The common genital opening is situated at about $80 \%$.

A pair of ovaries is situated caudally, near the adhesive belt. No further details of the female reproductive system could be observed.

The arrangement of the proboscis armature differs somewhat from the proboscis armature as described by Brunet (1979). In particular, the fields of spines are wider (four to six rows of spines, instead of just three or four). Carcharodorhynchus isolatus Schilke, 1970 has a very similar organisation of the proboscis teeth. However, rather than two fields of spines, interrupted by a short section in which the spines are in a single row, the spines form a long stretch of three to four continuous rows. Furthermore, $C$. isolatus has a substantially larger proboscis, even though the size of the proboscis teeth is approximately the same as those reported here. With a length of $15 \mu \mathrm{m}$, the cirrus of our Portuguese specimen is slightly longer than what has been described for $C$. tenuis $(9 \mu \mathrm{m})$. In addition, Brunet (1979) mentions a tubular shape, while our specimen displays a more conically-shaped cirrus. However, this difference is likely the result of either the flattening of the specimen or the state of contraction of the copulatory bulb (or a combination of both). 
Carcharodorhynchus flavidus Brunet, 1967

Fig. 3E-H

\section{Material examined}

PORTUGAL 1 whole-mount (photographs of live specimen available); Algarve region, Olhos de Água; $37^{\circ} 05^{\prime} 20^{\prime \prime} \mathrm{N}, 08^{\circ} 11^{\prime} 17^{\prime \prime} \mathrm{W}$; 15 May 2013; B. Tessens leg.; dry sand and algae mixture, scraped from stones at eastern side of the rocky outcrop; HU X.1.47 • 1 whole-mount (photographs of live specimen available); Algarve region, Ilha de Culatra; 36 $59^{\prime} 10^{\prime \prime}$ N, 0750'20" W; 17 May 2013; B. Tessens leg.; exposed beach opposite village, at $30 \mathrm{~cm}$ depth, slightly above low-water line; HU X.1.48 1 wholemount; Algarve region, Carvoeiro, beach below Vale de Covo; 37 05'34" N, 08 $27^{\prime} 35^{\prime \prime}$ W; 27 May 2013; B. Tessens leg.; algae and sand scraped from rocks; HU X.1.49.

USA - Hawaii - 1 whole-mount (photographs of live specimen available); Oahu, Waimãnalo Beach; $21^{\circ} 19^{\prime} 36^{\prime \prime}$ N, 157040'59" W; 28 May 2010; N. Van Steenkiste leg; fine sand with organic material in sheltered habitats between coral at approximately $1.5 \mathrm{~m}$ depth; HU X.4.01 1 whole-mount (photographs of live specimen available); Oahu, Waimãnalo Beach; $21^{\circ} 19^{\prime} 36^{\prime \prime} \mathrm{N}, 157^{\circ} 40^{\prime} 59^{\prime \prime} \mathrm{W}$; 31 May 2010; N. Van Steenkiste leg; fine sand with organic material in between coral rocks; HU X.4.02 • 1 whole-mount (photographs of live specimen available); same collection data as for preceding; HU X.4.03.

\section{Previously known distribution}

Bay of Marseille and nearby areas, Mediterranean, France (Brunet 1967); North Carolina, USA(Whitson et al. 2011); Lanzarote, Canary Islands, Spain (Gobert et al. 2017); Sardinia, Italy (Gobert et al. 2017).

\section{Remarks}

Live specimens are bright yellow. A single haptic girdle is present caudally. A large proboscis (Fig. 3E-F) is present at the rostral end of the body. The proboscis is armed with triangular denticles on the inwardfacing surface. The fields of denticles are interrupted at the base of the proboscis tongues, producing a 'basal gap', typical for C. flavidus. A pair of seminal vesicles enter the copulatory bulb (Fig. 3G-H) separately at its proximal end. Prostatic glands occur proximally in the ovoid copulatory bulb. Distally, it is provided with a straight cirrus, armed with small spines. The measurements of the Portuguese specimens fall within the size ranges previously reported in the literature (Brunet 1967; Whitson et al. 2011; Gobert et al. 2017).

Carcharodorhynchus flavidus has an extremely wide geographic range that includes the Atlantic, the Mediterranean and Hawaii. This, along with the rather great variation in size this species exhibits, as well as some variation in proboscis dentition, has prompted some authors to suggest that $C$. flavidus as described by Brunet (1967) may cover several species (Whitson et al. 2011; Gobert et al. 2017).

Carcharodorhynchus multidentatus Brunet, 1979

Fig. 3I-L

\section{Material examined}

PORTUGAL - 1 whole-mount (photographs of live specimen available); Algarve region, Faro; $36^{\circ} 57^{\prime} 01^{\prime \prime} \mathrm{N}, 07^{\circ} 57^{\prime} 35^{\prime \prime} \mathrm{W}$; 23 May 2013; B. Tessens leg.; coarse sand with shell debris from the exposed part of the barrier island opposite Faro at a depth of 26 m; HU X.1.50.

SPAIN • 1 whole-mount; Andalusia, west of Tarifa; 3601'56" N, 05³7'36" W; 30 Mar. 2008; B. Tessens and N. Van Steenkiste leg.; fine sand from a long beach; HU X.2.01. 


\section{Previously known distribution}

Bay of Marseille, France (Brunet 1979).

\section{Remarks}

Our observations on the specimens collected in Portugal and Spain largely correspond to Brunet's (1979) original description. Live specimens are transparent and measure 1.2-2.1 mm in length. A large proboscis, consisting of a pair of broad, flattened muscular tongues, is situated at the rostral body end (Fig. 3I-J). The proboscis is more or less symmetrical, though the ventral tongue is more rounded than

A.

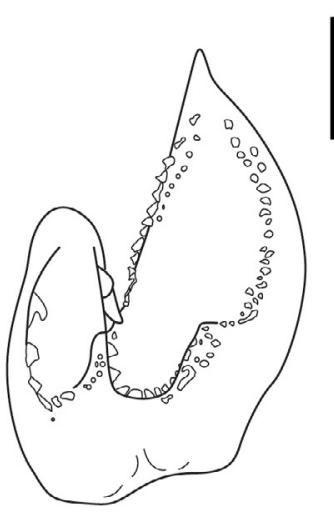

E.

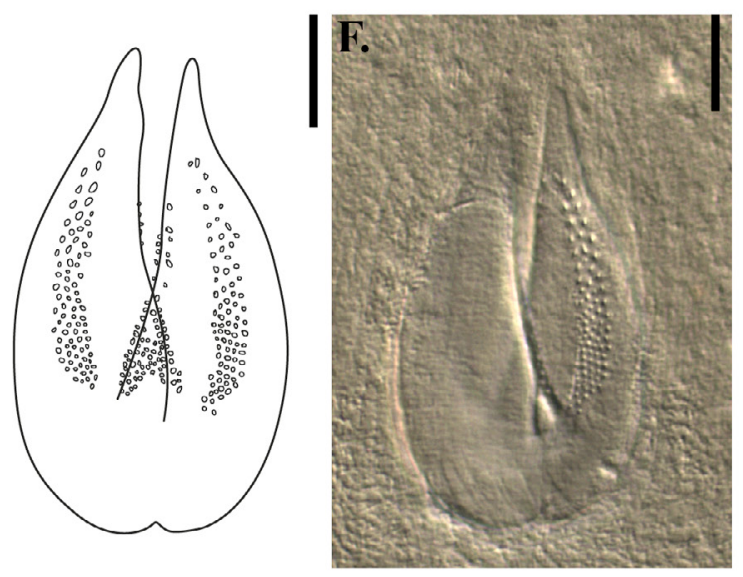

I.

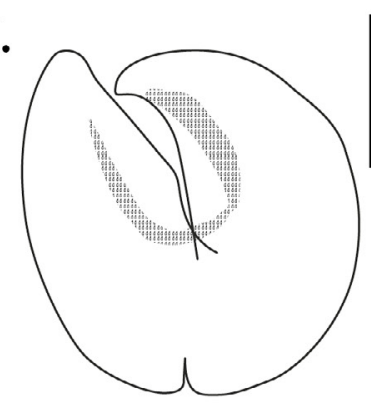

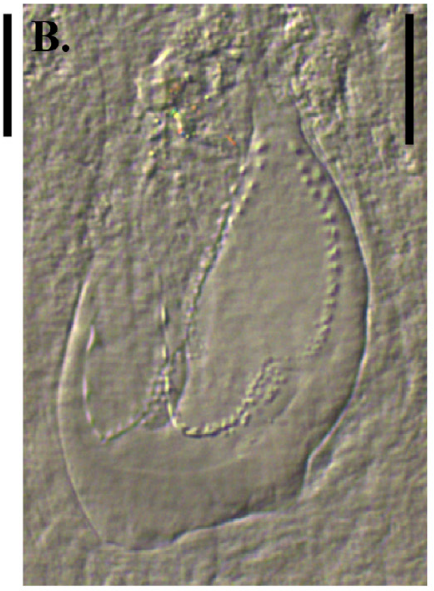

C.

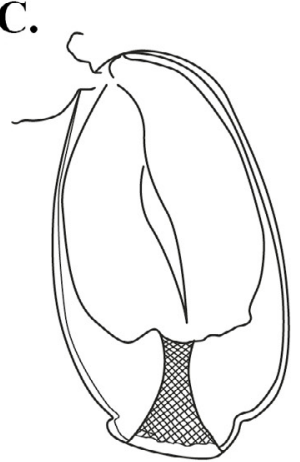

G.

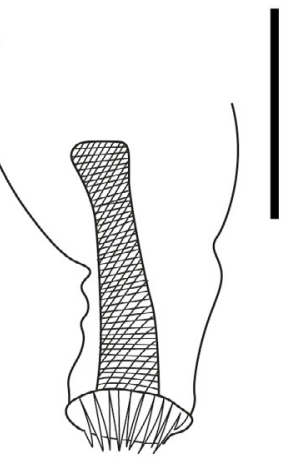

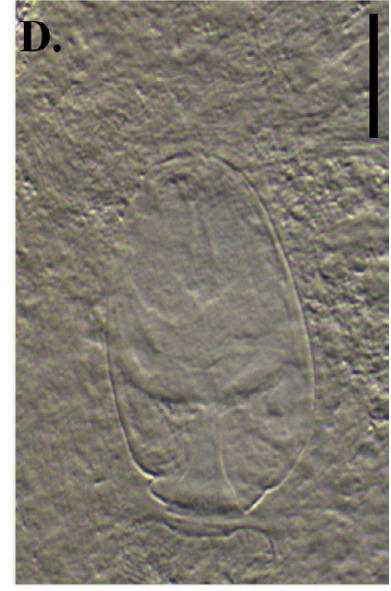
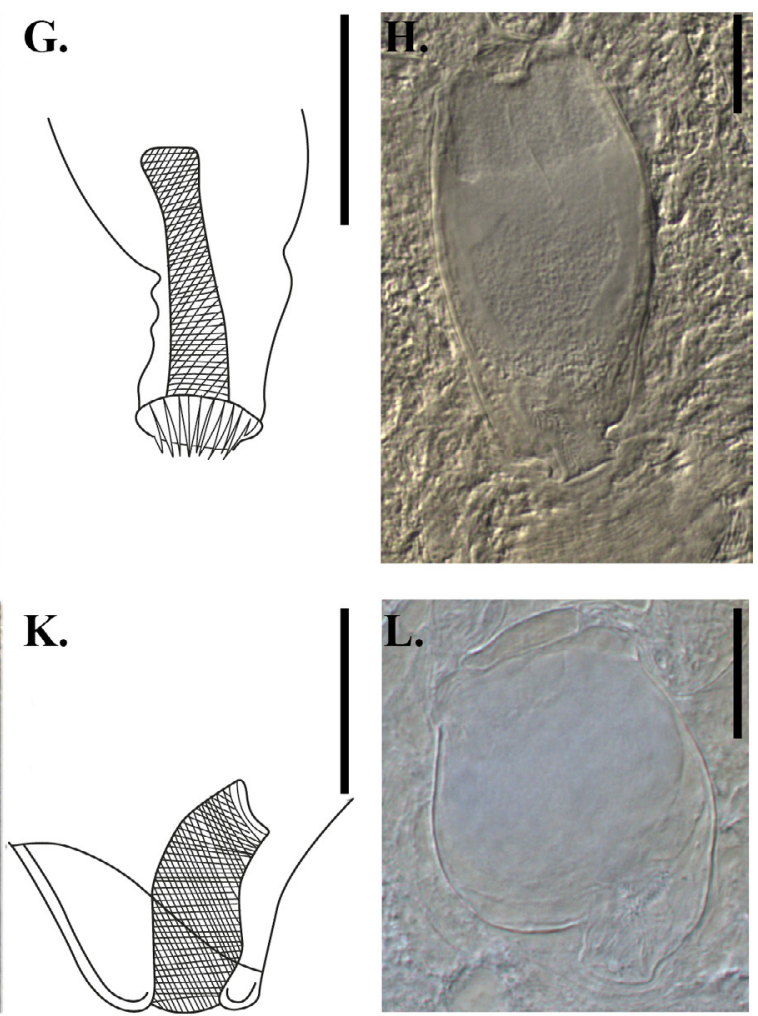

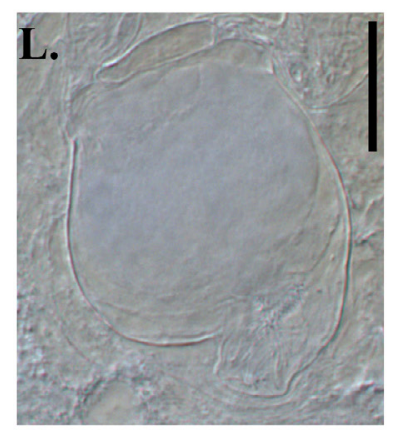

Fig. 3. A-D. Carcharodorhynchus tenuis Brunet, 1979 (HU X.1.46). A-B. Proboscis. C-D. Copulatory bulb. E-H. C. flavidus Brunet, 1967. E-F. Proboscis (HU X.1.49). G-H. Copulatory bulb (HU X.1.4849). I-L. C. multidentatus Brunet, 1979 (HU X.1.50). I-J. Proboscis. K-L. Copulatory organ. Scale bars: $20 \mu \mathrm{m}$. 
the dorsal tongue. Two fields of numerous, very fine, sclerotised denticles run continuously across the inward-facing surface of both proboscis tongues. The denticles are arranged in 7-10 rows. The size of the denticles is largest on the rows closest to the lateral sides of the proboscis tongues and smallest in the rows facing the middle of the proboscis tongues. A rosulate pharynx is situated in the caudal body half, at approximately $65 \%$ of the body length.

According to Brunet (1979), paired rows of two to three testes follicles run laterally in the rostral body half. In the specimen from Portugal, we observed only two large testes directly posterior to the proboscis. A pair of seminal vesicles empty into the proximal end of a short, ovoid-to-spherical copulatory bulb that is between 56 and $72 \mu \mathrm{m}$ long $(\overline{\mathrm{x}}=64 \mu \mathrm{m}, \mathrm{n}=2)$. The proximal half to two-thirds of the copulatory bulb contains a prostatic vesicle. The cirrus occupies the distal third of the copulatory bulb, is 15 to $21 \mu \mathrm{m}$ long and armed with minute spines, arranged in longitudinal rows. These measurements of the copulatory bulb are somewhat larger than what has been reported by Brunet (1979) (cb: 53-57 $\mu \mathrm{m}$, ci: $13-14 \mu \mathrm{m})$. A rather large size variation has also been reported in the copulatory organs of other species in the genus Carcharodorhynchus, such as C. flavidus (see above).

Brunet (1979) did not describe the female system. In one live specimen, we observed a single ovary, situated to one side near the caudal adhesive belt. We were unable to ascertain whether a second ovary was present.

The records mentioned here are the first published records of this species since its original description by Brunet (1979) and are the first records outside of the French Mediterranean. Furthermore, two specimens present in the reference collection of Hasselt University (HU VIII.1.30 and HU VIII.1.47), which were previously identified as C. flavidus (Gobert et al. 2017), are now correctly identified as C. multidentatus.

Family Diascorhynchidae Meixner, 1929

Genus Diascorhynchus Meixner, 1928

Diascorhynchus caligatus Ax, 1959

Fig. 4

\section{Material examined}

PORTUGAL - 1 whole-mount (photographs of live specimen available); Algarve region, Olhos de Água; $37^{\circ} 05^{\prime} 20^{\prime \prime} \mathrm{N}, 08^{\circ} 11^{\prime} 17^{\prime \prime} \mathrm{W}$; 15 May 2013; B. Tessens leg.; fine, clean sand from intertidal at open beach, west of rocky outcrop at depth of $0.5 \mathrm{~m}$; HU X.2.06.
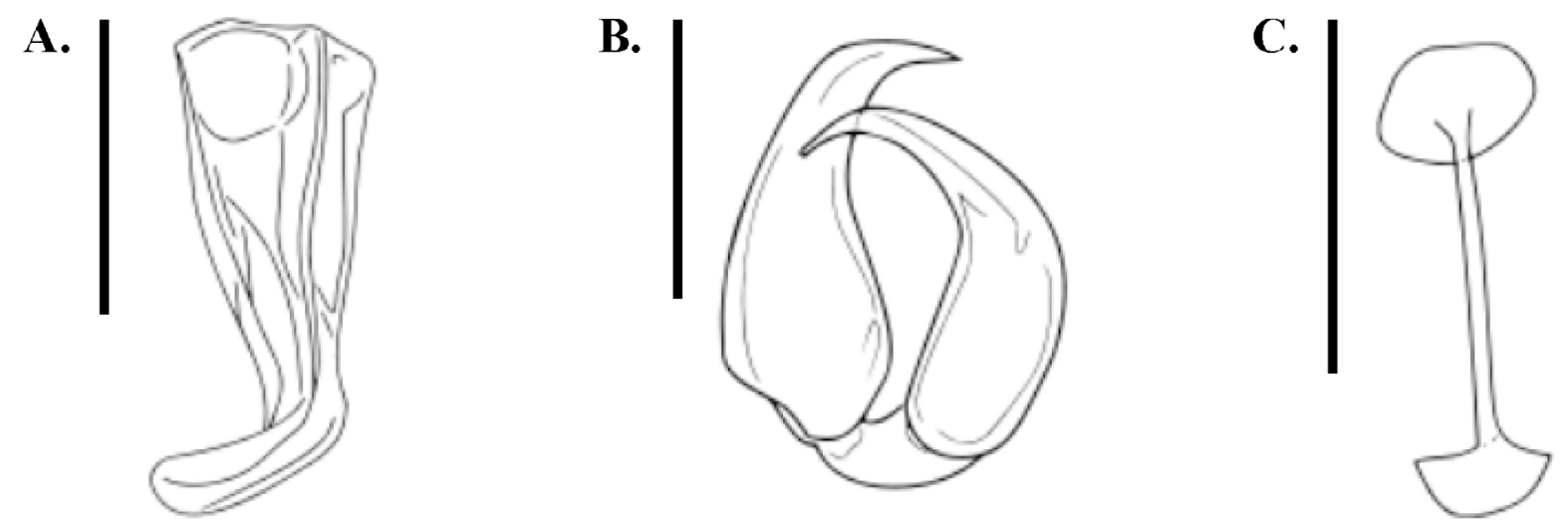

Fig. 4. Diascorhynchus caligatus Ax, 1959 (HU X.2.07). A. Stylet. B. Proboscis hooks. C. Sclerotised spermatic duct. Scale bars: $20 \mu \mathrm{m}$. 
SPAIN • 1 whole-mount; Andalusia, Doñana National Park; 6 Apr. 2008; B. Tessens and N. Van Steenkiste leg.; beach at $5 \mathrm{~km}$ from river mouth, sandy sediment from the lower tidal mark; HU X.2.07.

\section{Previously known distribution}

Sile, Black Sea, Turkey (Ax 1959).

\section{Remarks}

The overall habitus and internal organisation of the collected specimens correspond well to the description by $A x$ (1959). The body length measures between 1.6 and $1.7 \mathrm{~mm}$, which is at the lower end of the size range of 1.6-2.0 mm reported by Ax (1959). The split proboscis bears a pair of large, sclerotised hooks (Fig. 4B). The dorsal hook is more robust and measures 30-32 $\mu \mathrm{m}$ in length, while the ventral hook measures 31-34 $\mu \mathrm{m}$. Two elongate lateral gland sacs connect to the proximal end of the proboscis. The rosulate pharynx is situated slightly posterior to the body centre. Six globular testes lie in a single, medial row anterior to the pharynx.

The copulatory bulb varies in length between $61 \mu \mathrm{m}$ and $86 \mu \mathrm{m}$ and holds a sclerotised stylet (Fig. 4A). The stylet measures 42 to $48 \mu \mathrm{m}$. These measurements are in line with the descriptions of Ax (1959).

A single ovary and a bursa occur near the caudal body end. In the specimen from Doñana, we observed a sclerotised, spermatic duct, connecting the bursa to the ovary. Similar to what was described by Ax (1959), this duct is a straight tube, measuring around $26 \mu \mathrm{m}$ in length and terminating at both ends in a small, sclerotised disk (Fig. 4C). The spermatic duct was not observed in the Portuguese specimen. Vitellaria are paired and occur laterally, between the ovaries and the brain.

\section{Discussion}

Along with the newly-described species Schizochilus coninxae sp. nov., Proschizorhynchus algarvensis sp. nov., P. arnautsae sp. nov. and P. troglodytus sp. nov., all of the above-mentioned species are recorded from the Iberian Peninsula for the first time, bringing the total number of marine kalyptorhynch species in the area to 23, a near doubling of the number of species previously known from this region. For Schizorhynchia in particular, the number of species has increased almost threefold with this contribution, going from only five previously-reported species to a total of 14. Given the suggested ecological importance of Schizorhynchia and other flatworms in the meiobenthic environment (see Martens \& Schockaert 1986; Boaden 1995), a thorough understanding of meiobenthic ecology and biodiversity in the Iberian Peninsula will require much more intensive sampling of this fauna.

\section{Acknowledgements}

We thank the Ministerio de Educación y Ciencia and the Estación Biológica de Doñana (ICTS-RBD, Spain) for the financial and logistical support of the fieldwork in Doñana National Park. Collecting trips to the Algarve were financed by the EU FP7 ASSEMBLE grant agreement no. 227799. We would like to thank the Centro de Ciências do Mar (Centre of Marine Sciences) of the University of the Algarve, Portugal, for providing excellent working and sampling facilities, in particular Dr Ana Amaral for the kind and efficient logistic support and Dr Jorge Gonçalves for collecting the samples at the islands near Sagres. Special thanks also go to the captain of the Zodiac for his help with sampling in the Ria Formosa. The research of S.G. was supported by a PhD-grant of BOF-UHasselt. M.M. is funded by a $\mathrm{PhD}$ fellowship from the Research Foundation - Flanders (FWO-Vlaanderen). We would like to thank Ria Vanderspikken and Natascha Steffanie for their valuable assistance in the lab. Dr Bart Tessens and Dr Niels Van Steenkiste are thanked for their involvement in collecting specimens from the Algarve, Portugal and Doñana National Park, Spain. Dave Bosmans is cordially thanked for his help with processing the images included in this work 


\section{References}

Ax P. 1959. Zür Systematik, Ökologie und Tiergeographie der Turbellarienfauna in den ponto-kaspischen Brackwassergebieten. Zoologische Jahrbücher: Abteilung für Systematik, Ökologie und Geographie der Tiere 87: 43-184.

Boaden P.J.S. 1995. Where Turbellaria? Concerning knowledge and ignorance of marine turbellarian ecology. Hydrobiologia 305: 91-99. https://doi.org/10.1007/BF00036368

Brunet M. 1967. Turbellariés schizorhynques de la région de Marseille. Sur Carcharodorhynchus subterraneus et Carcharodorhynchus flavidus nov. sp. Bulletin de la société zoologique de France 92: $143-152$.

Brunet M. 1970. Turbellariés Schizorhynchidae de sables infralittoraux de la côte Marseillaise. Cahiers de Biologie Marine 11: 279-306.

Brunet M. 1979. Turbellaires Calyptorhynques du Golfe de Marseille. Revue de Biologie et Écologie méditerranéenne 6: 101-120.

de Beauchamp P. 1927. Rhabdocoeles des sables à diatomées d'Arcachon I. Coup d'œil sur l'association Schizorhynchidae. Bulletin de la société zoologique de France 52: 351-386.

Farías F., Gamo J. \& Noreña-Janssen C. 1995. Nuevas aportaciones al conocimiento de los microturbelarios de la Península Ibérica. Graellsia 51: 93-100. https://doi.org/10.3989/graellsia.1995.v51.i0.399

Gamo J. \& Noreña-Janssen C. 1998. Old and new records of turbellarians from the central areas of Spain. Hydrobiologia 383: 299-305. https://doi.org/10.1023/A:1003448029737

Gieysztor M. 1931. Contribution à la connaissance des Turbellariés Rhabdocoèles (Turbellaria Rhabdocoela) d'Espagne. Bulletin de l'Académie Polonaise des Sciences et des Lettres, Classe des Sciences Mathematiques et Naturelles B 2: 125-153.

Gobert S., Reygel P. \& Artois T. 2017. Schizorhynchia (Platyhelminthes Rhabdocoela) of Lanzarote (Canary Islands), with the description of eight new species. Marine Biodiversity.

https://doi.org/10.1007/s12526-017-0736-x

l'Hardy J.-P. 1965. Turbellaries Schizorhynchidae des sables de Roscoff II. Le genre Proschizorhynchus. Cahiers de Biologie Marine 6: 135-161.

Martens P.M. \& Schockaert E.R. 1986. The importance of turbellarians in the marine meiobenthos: a review. Hydrobiologia 132: 295-303. https://doi.org/10.1007/BF00046263

Noldt U. 1985. Typhlorhynchus syltensis n. sp. (Schizorhynchia, Plathelminthes) and the Adelphotaxarelationship of Typhlorhynchus and Proschizorhynchus. Microfauna Marina 2: 347-370.

Noldt U. \& Hoxhold S. 1984. Interstitielle Fauna von Galapagos. XXXIV. Schizorhynchia (Plathelminthes, Kalyptorhynchia). Microfauna Marina 1: 199-256.

Noreña C., del Campo A. \& del Real M. 1999. Taxonomy and morphology of limnic microturbellarians (Plathelminthes) in Extremadura (Spain). Hydrobiologia 397: 21-28.

https://doi.org/10.1023/A:1003565505722

Noreña C., Damborenea C., Faubel A. \& Brusa F. 2007. Composition of meiobenthonic Platyhelminthes from brackish environments of the Galician and Cantabrian coasts of Spain with the description of a new species of Djeziraia (Polycystididae, Kalyptorhynchia). Journal of Natural History 41: 1989-2005. https://doi.org/10.1080/00222930701526055

Schockaert E.R. 1996. Turbellarians. In: Hall G.S. (ed.) Methods for the Examination of Organismal Diversity in Soils and Sediments: 211-225. CAB International, UK. 
Schockaert E.R. 2014. Marine Macrostomorpha (Platyhelminthes, Rhabditophora) from the Algarve (Southern Portugal). Zootaxa 3872: 577-590. https://doi.org/10.11646/zootaxa.3872.5.8

Schockaert E.R., Jouk P.E.H. \& Martens P.M. 1989. Free-living Plathelminthes from the Belgian coast and adjacent areas. In: Wouters K. \& Baert L. (eds) Proceedings of the Symposium "Invertebrates of Belgium ": 19-25. Institut royal des Sciences naturelles de Belgique, Brussels.

Schockaert E.R., Tessens B., Gobert S., Revis N. \& Artois T.J. 2017. On the genus Gallorhynchus Schockaert \& Brunet, 1971 (Platyhelminthes, Kalyptorhynchia, Polycystididae) with the description of four new species. Zootaxa 4227: 61-74. https://doi.org/10.11646/zootaxa.4227.1.3

Schockaert E.R., Moons P., Janssen T., Tessens B.S., Reygel P.C., Revis N., Jouk P.E.H., Willems W.R. \& Artois T.J. 2019. On the genus Typhlopolycystis Karling, 1956 (Platyhelminthes, Kalyptorhynchia, Polycystididae), with data on the five known species and the description of eleven new species. Zootaxa 4603: 81-104. https://doi.org/10.11646/zootaxa.4603.1.4

Tessens B., Janssen T. \& Artois T. 2014. Molecular phylogeny of Kalyptorhynchia (Rhabdocoela, Platyhelminthes) inferred from ribosomal sequence data. Zoologica Scripta 43: 519-530.

https://doi.org/10.1111/zsc.12066

Tyler S., Artois T., Schilling S., Hooge M. \& Bush L.F. (eds) 2006-2019a. World List of turbellarian worms: Acoelomorpha, Catenulida, Rhabditophora. Proschizorhynchus Meixner, 1928. Available from http://www.marinespecies.org/aphia.php?p=taxdetails\&id=142393 [accessed 21 Aug. 2019].

Tyler S., Artois T., Schilling S., Hooge M. \& Bush L.F. (eds) 2006-2019b. World List of turbellarian worms: Acoelomorpha, Catenulida, Rhabditophora, Dalytyphloplanida. Available from http://www.marinespecies.org/aphia.php?p=taxdetails\&id=853126 [accessed 21 Aug. 2019].

Van Steenkiste N., Tessens B., Krznaric K. \& Artois T. 2011. Dalytyphloplanida (Platyhelminthes: Rhabdocoela) from Andalusia, Spain, with the description of four new species. Zootaxa 2791: 1-29.

https://doi.org/10.11646/zootaxa.2791.1.1

Whitson A., Smith III J.P.S. \& Litvaitis M.K. 2011. Lehardyia alleithoros, sp. nov. (Turbellaria, Kalyptorhynchia) from the coast of North Carolina, USA. Southeastern Naturalist 10: 221-232.

https://doi.org/10.1656/058.010.0203

Willems W.R., Wallberg A., Jondelius U., Littlewood D.T.J., Backeljau T., Schockaert E.R. \& Artois T.J. 2006. Filling a gap in the phylogeny of flatworms: relationships within the Rhabdocoela (Platyhelminthes), inferred from 18S ribosomal DNA sequences. Zoologica Scripta 35: 1-17.

https://doi.org/10.1111/j.1463-6409.2005.00216.x

Manuscript received: 15 April 2019

Manuscript accepted: 24 September 2019

Published on: 21 January 2020

Topic editor: Rudy Jocqué

Desk editor: Pepe Fernández

Printed versions of all papers are also deposited in the libraries of the institutes that are members of the EJT consortium: Muséum national d'histoire naturelle, Paris, France; Meise Botanic Garden, Belgium; Royal Museum for Central Africa, Tervuren, Belgium; Royal Belgian Institute of Natural Sciences, Brussels, Belgium; Natural History Museum of Denmark, Copenhagen, Denmark; Naturalis Biodiversity Center, Leiden, the Netherlands; Museo Nacional de Ciencias Naturales-CSIC, Madrid, Spain; Real Jardín Botánico de Madrid CSIC, Spain; Zoological Research Museum Alexander Koenig, Bonn, Germany; National Museum, Prague, Czech Republic. 